Annals of Warsaw University of Life Sciences - SGGW

Land Reclamation No 47 (2), 2015: 173-182

(Ann. Warsaw Univ. Life Sci. - SGGW, Land Reclam. 47 (2), 2015)

\title{
Plastic flow rule for sands with friction, dilation, density and stress state coupling
}

\author{
MAREK WOJCIECHOWSKI \\ Chair of Geotechnics and Engineering Structures, Technical University of Lodz
}

\begin{abstract}
Plastic flow rule for sands with friction, dilation, density and stress state coupling. In this paper we propose a flow rule and failure criterion for sands in plane strain conditions based on Drucker-Prager formulation and enhanced with empirical Houlsby formula, which couples friction, dilation, density and stress state in the material. The resulting elasto-plastic, non-associated, shear hardening material model is implemented as a numerical procedure in the frame of finite element method and a simple compression example is presented. Because of the empirical nature of Houlsby formula, it is believed that results of numerical simulations will be more realistic both in deformation and shear strength estimation of sands.
\end{abstract}

Key words: Drucker-Prager, Houlsby formula, elasto-plasticity, dilatancy angle

\section{INTRODUCTION}

Elasto-plastic constitutive soil models are extensively used in numerical analysis of geotechnical structures (Zienkiewicz et al. 1999, Hicher and Shao 2013). The key ingredients of such models are: the yield function which determines the admissible stress states and the so-called plastic potential which defines direction of plastic flow of yielding material. In case of soils these two scalar valued functions are usually considered to be not equivalent, i.e. non-associative mod- els are developed. Moreover the shape of these functions depend on history and the current state of the material and in this context hardening and softening soil models are investigated. In case of granular media, like sands, the plastic behavior on shear is influenced mostly by the current hydrostatic stress and the relative density of the material. Other variables, like grain shape and size (Cox 2008), are also considered in this context.

Pressure dependence is inscribed into yield functions used commonly in soil mechanics like Mohr-Coulomb, Drucker-Prager, Matsuoka-Nakai. In original formulations of these functions the friction angle parameter is considered to be constant. Similarly the related plastic potential functions are parameterized with constant dilation angle. Soil models with shear hardening, will take into account interdependence between friction and dilation parameters and their relation to other material state parameters, see for example Mróz et al. (1983), Schanz et al. (1999), Chu et al. (2010) and many others. In these models dilation plays a key role, especially in soils denser than their critical state, which is almost always in case of natural sand or gravel deposits. 
In this paper we propose such a hardening failure criterion and a flow rule for sands in plane strain conditions. The key idea is given by Bolton (1986), who suggested that the friction angle is the sum of the critical friction angle and the dilation angle, and the dilation angle is the function of the mean effective stress and the relative density. The dilatancy will vanish when critical state is reached. Houlsby (1991) used Schofield and Wroth (1968) critical state line function combining Bolton's empirical fit to give a flow rule. Stress state, relative density, friction angle and dilation angle are then coupled and both, yield function and plastic potential shapes are evolving with their changes under loading and this is what we call shear hardening (softening) behavior.

In the following we present the governing equations for elasto-plasticity and we formulate the Drucker-Prager type yield function and plastic potential. Next we present the Houlsby formula and its consequences when it is used as a flow rule. Finally, illustrative numerical results are provided. To the best of our knowledge the Houlsby formula was not yet used in the numerical context presented in this paper.

\section{MATERIAL AND METHODS}

\section{Elasto-plasticity - governing equations and solution}

We will consider non-associated elasto-plasticity under regime of small strains where the classical additive decomposi- tion of strain rate tensor into elastic and plastic part can be given:

$$
\dot{\varepsilon}_{i j}=\dot{\varepsilon}_{i j}^{e}+\dot{\varepsilon}_{i j}^{p}
$$

The elastic part of strain rate is related to the stress rate tensor via Hook's law:

$$
\dot{\sigma}_{i j}=C_{i j k l} \dot{\varepsilon}_{k l}^{e}
$$

where $C_{i j k l}$ is a fourth order elastic tangent stiffness tensor. The plastic part of the strain rate is given by the flow rule:

$$
\dot{\varepsilon}_{i j}^{p}=\dot{\gamma} M_{i j}
$$

where $\dot{\gamma}$ is a magnitude of the plastic strain rate and $M_{i j}$ is a tensor representing direction of the plastic flow. Plastic strain rate direction is commonly obtained as a normal to the function $g\left(\sigma_{i j}\right)$, called plastic potential:

$$
M_{i j}=\frac{\partial g\left(\sigma_{i j}\right)}{\partial \sigma_{i j}}
$$

We introduce now a scalar yield function $f\left(\sigma_{i j}\right)$ which determines possible stress states in the material. By convention if $f\left(\sigma_{i j}\right)<0$, then the deformation is purely elastic, if $f\left(\sigma_{i j}\right)=0$, then continued plastic deformation occurs and the $f\left(\sigma_{i j}\right)>0$ is not allowed.

When plastic flow occurs it is assumed that $f\left(\sigma_{i j}\right)$ remains equal to zero. This is the so called consistency condition and is written as:

$$
\dot{f}\left(\sigma_{i j}\right)=\frac{\partial f}{\partial \sigma_{i j}} \frac{\partial \sigma_{i j}}{\partial t}=B_{i j} \dot{\sigma}_{i j}=0
$$

where $B_{i j}$ is a gradient of yield function at the current stress state. 
Solution of the above governing equations goes as follows. We introduce equation (3) to (1) having:

$$
\dot{\varepsilon}_{i j}^{e}=\dot{\varepsilon}_{i j}-\dot{\gamma} M_{i j}
$$

Introducing the above to (2) we get:

$$
\dot{\sigma}_{i j}=C_{i j k l} \dot{\varepsilon}_{k l}-\dot{\gamma} C_{i j k l} M_{k l}
$$

Substituting:

$$
C_{i j k l} \dot{\varepsilon}_{k l}=\dot{\sigma}_{i j}^{\text {trial }}
$$

and

$$
C_{i j k l} M_{k l}=A_{i j}
$$

we have:

$$
\dot{\sigma}_{i j}=\dot{\sigma}_{i j}^{\text {trial }}-\dot{\gamma} A_{i j}
$$

Let's insert now the above equation to (5):

$$
B_{i j} \dot{\sigma}_{i j}^{\text {trial }}-\dot{\gamma}\left(B_{i j} A_{i j}\right)=0
$$

what give us the positive scalar $\dot{\gamma}$, as:

$$
\dot{\gamma}=\frac{B_{i j} \dot{\sigma}_{i j}^{\text {trial }}}{A_{i j} B_{i j}}
$$

Replacing this result in (10) give us finally:

$$
\dot{\sigma}_{i j}=\dot{\sigma}_{i j}^{\text {trial }}-\frac{B_{k l} \dot{\sigma}_{k l}^{\text {trial }}}{A_{k l} B_{k l}} A_{i j}
$$

Recalling that $B_{i j}$ is a tensor normal to the yield function the above equation is geometrically interpreted as an oblique projection of the trial elastic stress rate to the yield function (Brannon 2002). Direction of this projection is given by tensor $A_{i j}$ defined by (9), whereas the plane of projection is given by normal $B_{i j}$ to the yield function. Note that none of the tensors used in this equation needs to be unitary.

For finite element method analysis an elasto-plastic tangent stiffness tensor is also derived, relating strain rate to stress rate. It is given by:

$$
\dot{\sigma}_{i j}=\left(C_{i j k l} \frac{A_{i j} B_{m n} C_{m n k l}}{A_{p q} B_{p q}}\right) \dot{\varepsilon}_{k l}=C_{i j k l}^{e p} \dot{\varepsilon}_{k l}
$$

\section{Drucker-Prager yield function and plastic potential}

Assuming negative sign of compressive normal stresses, the Drucker-Prager (DP) yield function can be written as:

$$
f\left(\sigma_{i j}\right)=\sqrt{J_{2}}+\alpha I_{1}-k
$$

with:

$J_{2} \quad$ - second invariant of the stress deviator $\left(s_{i j}\right)$;

$I_{1} \quad$ - first invariant of stress tensor;

$\alpha, k$-parameters given in terms of peak friction angle $(\phi)$ and cohesion (c).

In case we use compression fit of Mohr-Coulomb (MC) yield surface (Maïolino and Luong 2009) these parameters are given by:

$$
\begin{aligned}
& \alpha=\frac{2 \sin \phi}{\sqrt{3(3-\sin \phi)}} \\
& k=\frac{6 c \cos \phi}{\sqrt{3(3-\sin \phi)}}
\end{aligned}
$$


For sands $k$ is assumed to be zero, because of no cohesion. Normal to this yield function is then written as:

$$
\frac{\partial f}{\partial \sigma_{i j}}=B_{i j}=\frac{s_{i j}}{2 \sqrt{J_{2}}}+\alpha \delta_{i j}
$$

where $\delta_{i j}$ is Kronecker's delta. Similarly, the plastic potential function of the form:

$$
g\left(\sigma_{i j}\right)=\sqrt{J_{2}}+\beta I_{1}
$$

can be used, with $\beta$ commonly taken as:

$$
\beta=\frac{2 \sin \psi}{\sqrt{3(3-\sin \psi)}}
$$

where $\psi$ is known as a dilation angle. Normal to the plastic potential is then given as:

$$
\frac{\partial g}{\partial \sigma_{i j}}=M_{i j}=\frac{s_{i j}}{2 \sqrt{J_{2}}}+\beta \delta_{i j}
$$

\section{Friction, dilatancy and stress state coupling}

It is known from laboratory evidence that both frictional parameters $\phi$ and $\psi$ are not constants and in general they depend on each other, on the current density of the material and on the current stress state. This dependence is especially visible in case of non-cohesive soils, like sands and gravels. For sands in plane strain conditions the Houlsby formula (Houlsby 1991) for dilation angle can be used (Fig. 1):

$$
\psi=-0.11+0.59 I_{D}-0.11 I_{D} \ln \left(-\frac{p}{p_{a}}\right)
$$

where:

$I_{D}$ - relative density;

$p-$ mean effective stress (negative);

$p_{a}$-atmospheric pressure (positive).

This formula clearly covers the effect of increase of the dilation angle due to increasing relative density and its decrease due to growing hydrostatic stress.

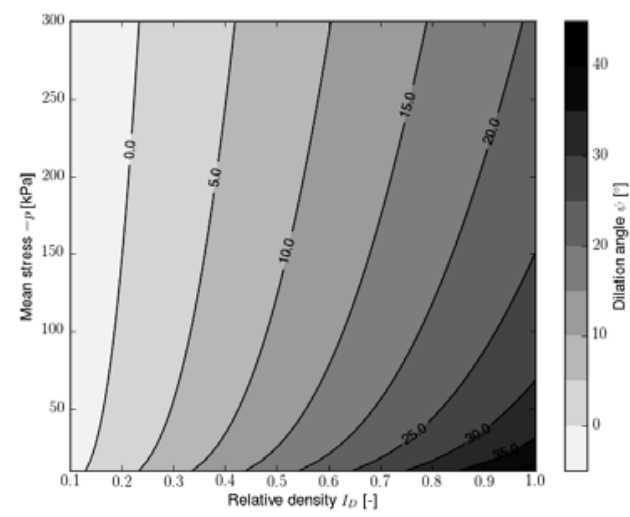

FIGURE 1. Dilation angle for sands with respect to relative density and mean stress according to Houlsby formula. No dilatancy ( 0.0 line) is present for critical state density

The peak friction angle defining the failure yield surface can be then calculated from Bolton (1986) experimental relation:

$$
\phi=\phi_{c s}+0.8 \psi
$$

where $\phi_{c s}$ is the critical state friction angle assumed to be constant, i.e. not related to the density nor stress state. This value can be treated as the material parameter and it can be calculated from given initial $\phi$ and $\psi$ values established for the same stress state and density index or it can be derived directly from laboratory tests. 
Introducing relations (22) and (23) into definitions of Drucker-Prager yield surface (15) and plastic potential (19) result in new failure criterion and flow rule. The shape changes of the modified yield surface $f$ for $\phi_{c s}=30^{\circ}$ are shown on Figure 2. The minimum and maxi- mum values of hardening parameter $I_{D}$ constitute clear boundaries for the possible yield loci. The failure lines are not straight anymore but the slight curvature is observed. Non-linearity of the flow rule is possibly more clear on the plastic potential $g$ graph in Figure 3.

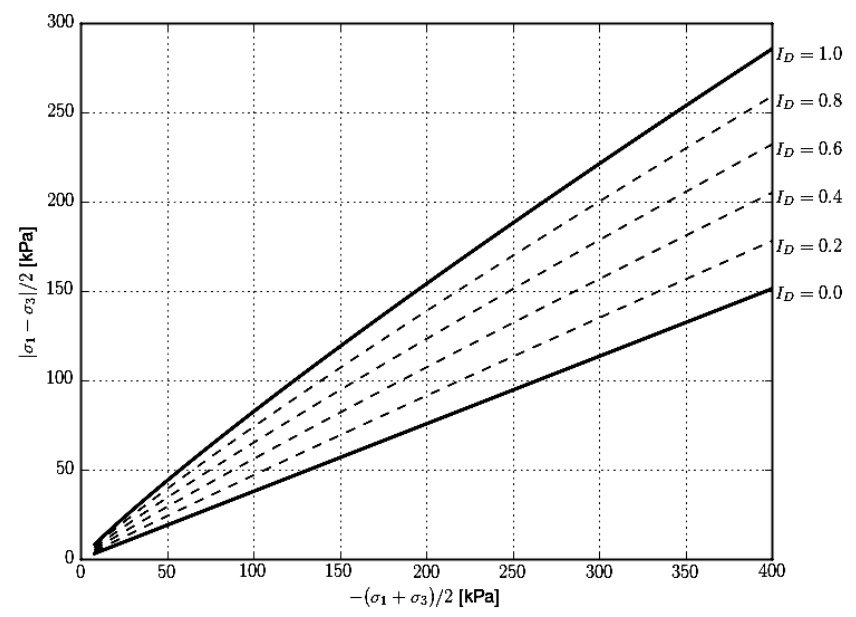

FIGURE 2. Shape changes of the yield surface $f$ for $\phi_{c s}=30^{\circ}\left(\sigma_{1}, \sigma_{3}\right.$ - principal stresses $)$

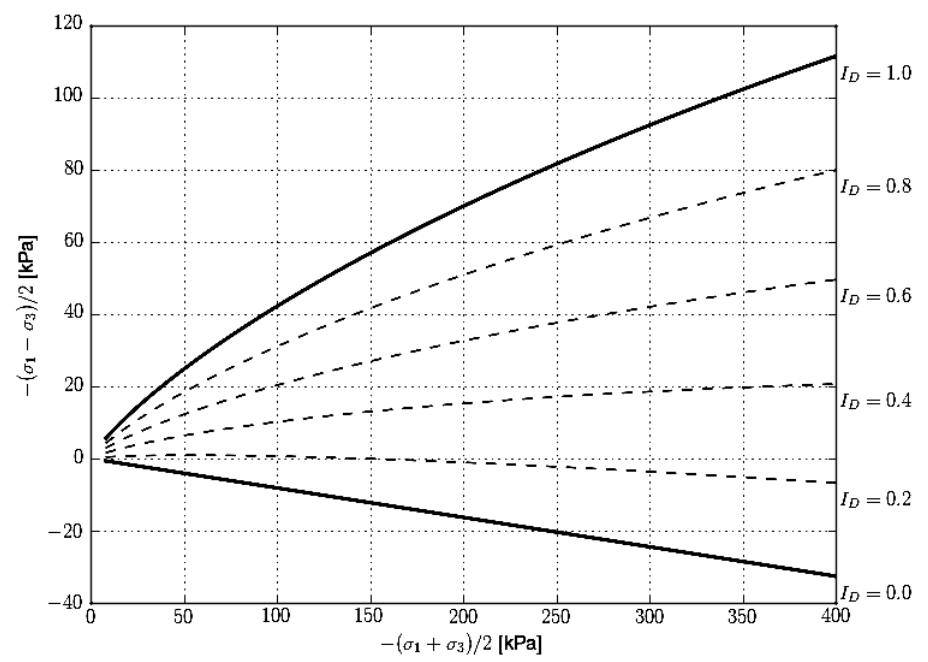

FIGURE 3. Shape changes of the plastic potential $g$ for $\phi_{c s}=30^{\circ}\left(\sigma_{1}, \sigma_{3}\right.$ principal stresses $)$ 


\section{RESULTS AND DISCUSSION}

\section{Numerical implementation}

The considered non-associated DruckerPrager criterion with shear hardening driven by relative density has been implemented as a numerical procedure in the frame of finite element method software - fempy (Wojciechowski 2014). Current implementation assumes slow evolution of density and mean stress what allows for linearization of yield function and plastic potential during single loading step. Calculation starts with the initial values $I_{D 0}, p_{0}$, and, after each loading step, the state variables are updated at all points of numerical integration. Current relative density is calculated from:

$$
I_{D}=I_{D 0}+\varepsilon_{v}\left(I_{D 0}-\frac{e_{\max }}{e_{\max }-e_{\min }}\right)
$$

where:

$\varepsilon_{v}=\varepsilon_{i i} \quad$ - current volumetric strain (negative for compression);

$e_{\max }, e_{\min }-$ maximum and minimum void ratios (being material constants).

After $I_{D}$ and $p$ update the dilation angle $\psi$, friction angle $\phi$, yield function $f$, plastic potential $g$, their derivatives $B_{i j}, M_{i j}$ and elasto-plastic tangent stiffness tensor $C_{i j k l}^{e p}$ are recalculated for new loading step. Solution process is driven by Newton-Krylov method (Knoll and Keyes 2004) and implicit integration of stress increments is used.

\section{Numerical example}

For demonstration purposes a simple plane strain compression problem has been performed. The rectangular sample of dimensions $35 \times 70 \mathrm{~mm}$ is filled by a moderately compacted medium sand with the relative density index $I_{D 0}=0.4$ and void ratios limits $e_{\min }=0.3$ and $e_{\max }=$ $=0.75$. It is assumed that the critical state friction angle is known and takes the value $\phi_{c s}=30^{\circ}$. Assuming the initial mean stress $p_{0}=-150 \mathrm{kPa}$, the value of the initial dilation angle $\psi=6.25^{\circ}$ is calculated from (22) and peak friction angle $\phi=35^{\circ}$ is taken from (23). Current numerical implementation does not include evolution of elastic properties with density changes thus constant Young modulus $E=50 \mathrm{MPa}$ and Poisson's ratio $v=0.25$ are taken for this example.

Sample has been first isotropically compressed with the initial stress $p_{0}=$ $=-150 \mathrm{kPa}$. Next the bottom edge was fixed and the top was loaded by vertical displacement up to the value $2 \mathrm{~mm}$ keeping the top horizontal displacements equal to zero. Distribution of the plastic volumetric strains, mean stress, relative density and dilation angle inside the sample after final loading step are shown on Figure 4. Clear plastic zones with loosening of the material are visible on the volumetric strain picture. In these zones also the dilation angle decreases most significantly (because of loosening). Also the increase of stresses leads to decrease of dilation angle with most significant changes near the top and bottom edges, where the mean compression stresses are the largest. 

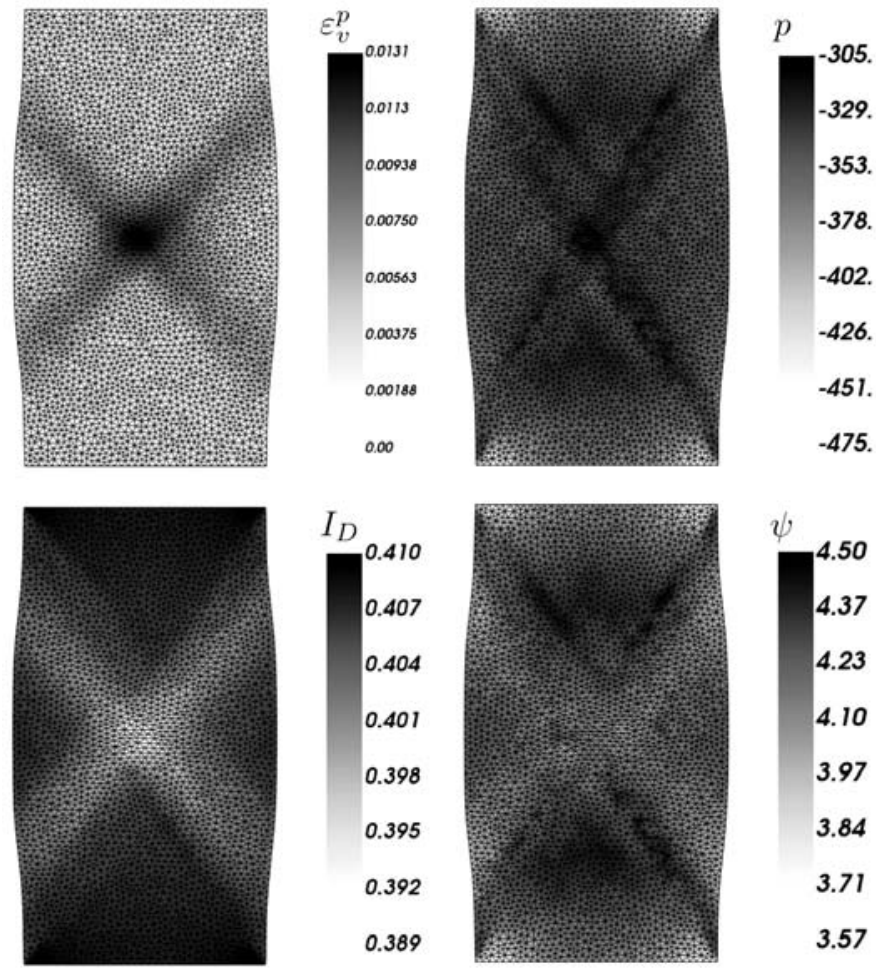

FIGURE 4. Plastic volumetric strains: $\varepsilon_{v}^{p}=\varepsilon_{i i}^{p}[-]$, mean stress, $p$ [kPa], relative density, $I_{D}[-]$ and dilation angle, $\psi\left[{ }^{\circ}\right]$ for the loaded sample

For comparison purposes similar calculation was performed by means of regular non-associated Drucker-Prager failure criterion with initial friction and dilation angles. Evolution of volume changes at the center point of the sample for both calculations is shown on Figure 5. After initial elastic compression material starts to dilate plastically and the rate of volume change is clearly smaller when dilation angle is evolving. It's worth to note that possible maximum volume change is limited in this case since continuous plastic loosening leads to decrease of dilation angle and, in extreme cases, can lead to plastic contraction. This is not true when $\psi$ is constant - plastic volume change is then always positive and is not limited. On Figure 6 deviatoric stresses are shown, also at sample center point. The strength of the material is clearly lower when dilation angle is evolving. This behavior is introduced directly by Bolton equation (23), and would not be present if simply regular non-associated Drucker-Prager criterion with decreased dilation angle is used. Also in case of evolving dilation angle the stress deviator starts to decrease after reaching the peak value, 


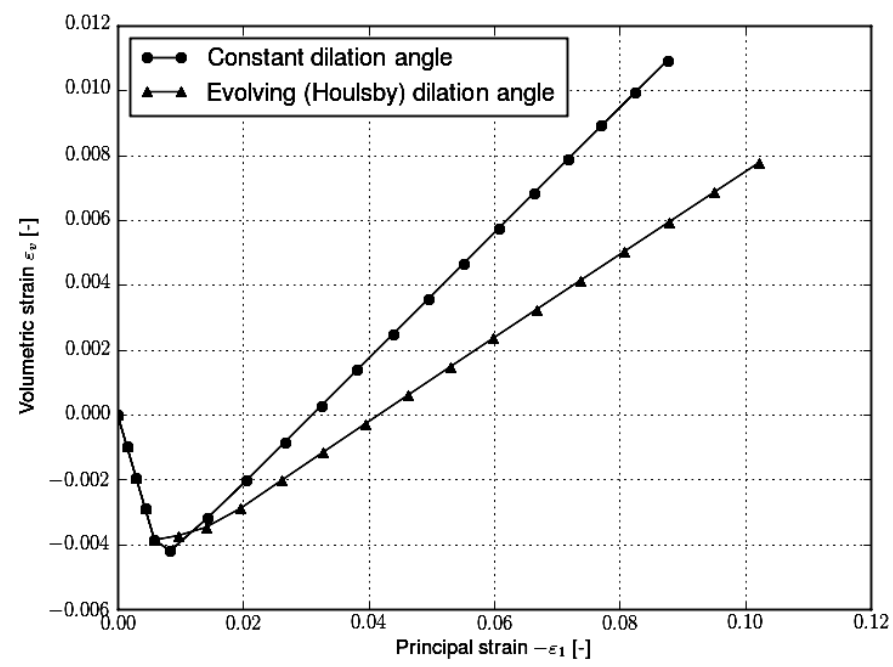

FIGURE 5. Volume changes at the center point of the loaded sample for evolving and constant dilation angle

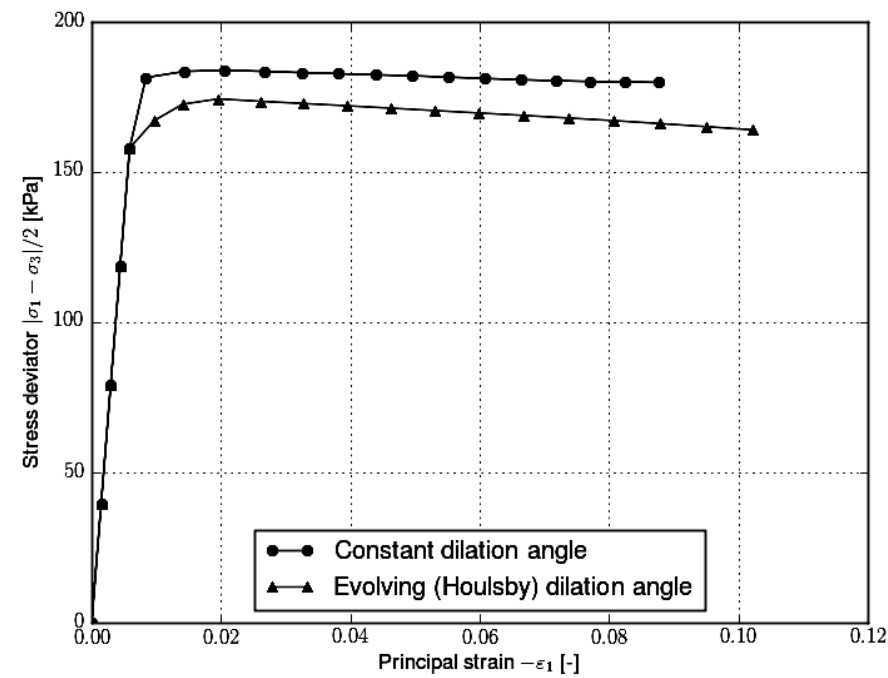

FIGURE 6. Stress deviator changes at the center point of the loaded sample for evolving and constant dilation angle

what is almost not visible in case of constant dilation and friction angles. Clearly modified flow rule covers the fact that material strength decreases when plastic loosening proceeds.

\section{CONCLUSIONS}

Houlsby empirical formula relating dilation angle with relative density and mean stress has been investigated and used as a flow rule in numerical simula- 
tion of sand in plane strain conditions. The formula showed to be useful in this numerical context and it is believed that results of simulations are more realistic both in deformation and shear strength estimation, when it is applied. The following additional remarks can also be drawn here:

- Drucker-Prager criterion is used in this paper for modeling plastic behavior of sand, however this is just a matter of choice; other yield function and plastic potential can also be used, unless they use friction and dilation angles as input parameters (e.g. Mohr-Coulomb or Matsuoka-Nakai);

- in numerical example, the peak strength of the material is determined by current relative density and mean stress and also the post peak softening behavior is covered; this is an advantage in comparison to regular non-evolving Drucker-Prager flow rule;

- plastic loosening of the material will be limited if modified flow rule is used; plastic volume changes will tend to zero when critical state $\psi=0, \phi=\phi_{c s}$ is approached; however reaching this state is virtually not possible in numerical simulation with small strains assumption;

- better covering of laboratory tests needs to enrich the model also with evolution of the elastic properties; such double hardening of the material is present for example in the model of Schanz et al. (1999); Houlsby formula investigated here can be used as an alternative for shear hardening part of such models.

Finally it is concluded that application of the considered empirical formula do not increase numerical cost of general implementation of elasto-plasticity. However, if we take for comparison simple yield functions, like regular DruckerPrager one, where the directions $B_{i j}, M_{i j}$ are constant, and do not need to be constantly recalculated, the additional costs could be remarkable.

\section{REFERENCES}

BOLTON M.D. 1986: The strength and dilatancy of sands. Geotechnique 36 (1), 65-78.

BRANNON R.M. 2002: Geometric insight into return mapping plasticity algorithms, http:// www.mech.utah.edu/brannon/public/radialreturn.pdf.

CHU BL., JOU YW., WENG MC. 2010: A constitutive model for gravelly soils considering shear-induced volumetric deformation. Canadian Geotechnical Journal 47 (6), 662-673.

COX M.R.B 2008: The influence of grain shape on dilatancy. PhD thesis, ProQuest.com.

HICHER P.Y., SHAO J.F. 2013: Constitutive modeling of soils and rocks, John Wiley \& Sons, New York.

HOULSBY G.T. 1991: How the dilatancy of soils affects their behaviour. University of Oxford, Department of Engineering Science.

KNOLL D.A., KEYES D.E. 2004: Jacobian-free Newton-Krylov methods: a survey of approaches and applications. Journal of Computational Physics 193 (2), 357-397.

MAïOLINO S., LUONG M.P. 2009: Measuring discrepancies between Coulomb and other geotechnical criteria: Drucker-Prager and Matsuoka-Nakai. 7th Euromech solid mechanics conference, Lisbon, Portugal, 09-07. 
MRÓZ Z., PIETRUSZCZAK S.T. 1983: A constitutive model for sand with anisotropic hardening rule. International Journal for $\mathrm{Nu}$ merical and Analytical Methods in Geomechanics 7 (3), 305-320.

SCHANZ T., VERMEER P.A., BONNIER P.G. 1999: The hardening soil model: formulation and verification. Beyond 2000 in computational geotechnics, Balkema, Rotterdam 1999, 281-296.

SCHOFIELD A., WROTH P. 1968: Critical state soil mechanics. McGraw-Hill, London.

WOJCIECHOWSKI M. 2014: Fempy - finite element method in python, http://geotech. p.lodz.pl:5080/fempy, http://fempy.org.

ZIENKIEWICZ O., CHAN A., PASTOR M., SCHREFLER B.A., SHIOMI T. 1999: Computational geomechanics. John Wiley \& Sons, New York.

Streszczenie: Prawo plastycznego ptynięcia dla piasków ze sprzężeniem tarcia, dylatancji, gęstości oraz stanu naprężenia. W artykule zaproponowano prawo płynięcia oraz kryterium zniszczenia dla piasków w warunkach płaskiego stanu odkształcenia oparte na sformułowaniu Druckera-Pragera i wzbogacone o empiryczną zależność Houlsby'ego wiążącą tarcie, dylatancję, gęstość i stan naprężenia w materiale. Uzyskany sprężysto-plastyczny, niestowarzyszony, ze wzmocnieniem na ścinanie model materiału zaimplementowano jako procedurę numeryczną w ramach metody elementów skończonych i zaprezentowano prosty przykład obliczeń dla zagadnienia ściskania. Z uwagi na doświadczalny charakter formuły Houlsby'ego, uważa się, że w przypadku stosowania proponowanego modelu wyniki symulacji numerycznych będą bliższe rzeczywistości, zarówno w zakresie szacowania odkształceń, jak i wytrzymałości na ścinanie piasków.

Słowa kluczowe: Drucker-Prager, zależność Houlsby'ego, sprężysto-plastyczność, kąt dylatancji

MS. received May 2015

\section{Authors' addresses:}

Marek Wojciechowski

Katedra Genetyki i Budowli Inżynierskich

Wydział Budownictwa, Architektury i Inżynierii

Środowiska

Politechnika Łódzka

al. Politechniki 6, 90-924 Łódź

Poland

e-mail: mwojc@p.lodz.pl 